\title{
金属ナノ共振器とシリコン導波路の集積化による光通信用減衰器の製作
}

\author{
金森 義明, 高橋 大洋, 羽根一博 \\ 東北大学大学院 工学研究科ナノメカニクス専攻 ( T980-8579 宮城県仙台市青葉区荒巻青葉6-6-01)
}

\section{Fabrication of Optical Attenuators for Optical Communication Based on Integration of Metal- Nanophotonic Resonators and Silicon Waveguides}

\author{
Yoshiaki KANAMORI, Taiyo TAKAHASHI, and Kazuhiro HANE \\ Department of Nanomechanics, Tohoku University, 6-6-01 Aoba, Aramaki, Aoba-ku, Sendai, Miyagi 980-8579
}

(Received September 15, 2015)

\begin{abstract}
Plasmonic metamaterials with artificial subwavelength structures are attracting much attention. Metal nano-rods are typical plasmonic metamaterials and function as nanophotonic resonators. At the resonant conditions in the visible and near-infrared regions, the electromagnetic waves at the resonant wavelengths strongly couple with the nano-rods and are absorbed due to Joule and radiative losses. Therefore, ultrasmall wavelength-selective absorbers can be made that consist of metal nano-rods. We fabricated wavelength-selective optical attenuators, which are comprised of Au nano-rods that are integrated with silicon waveguides for optical communications. The nano-rods and silicon waveguide were fabricated on silicon-on-insulator substrates with micromachining technologies. An evanescent wave of a propagating light into the silicon waveguide was coupled with a surface-plasmon-polariton mode of the Au nano-rods at a resonant wavelength and efficiently absorbed. At a wavelength of 1565 $\mathrm{nm}$, we observed optical attenuation of $-17.7 \mathrm{~dB}$.
\end{abstract}

Key Words: Metamaterials, Plasmonics, Micromachining, Silicon photonics, Optical attenuators

1. はじめに

メタマテリアルは，サブ波長構造を単位素子とした人 工光学物質である。メタマテリアルは微小な共振器とし て動作し, 共振器に励起された表面プラズモンポラリト ン (Surface Plasmon Polariton: SPP) が電磁波に対して電気 的または磁気的な応答を示すことにより, 共振特性に応 じて巨視的な誘電率や透磁率の変化, すなわち屈折率を 変化させる ${ }^{1-4)}$. 負の屈折率や巨大群屈折率など自然界に 存在しない光学応答や, 回折限界を超えたサブ波長空間 への電磁場局在を実現でき, これまでの光波操作の範疇 を超える新たな技術として期待されている. 可視〜近赤 外波長になると, メ夕マテリアルを構成する金属 $(\mathrm{Au}$, $\mathrm{Ag}, \mathrm{Al}$ など)のジュール損失が増大する。従って共振周 波数において吸収ピークが生じることから，メタマテリ アルを用いた波長選択アブソーバーが実現できる ${ }^{5-7)}$. 近赤外波長においては，2011年にZhangらが棈円形の金 属ナノディスク構造を基板上にアレイ配置したアブソー バーを試作した5)。なお，これまでに報告されている多 くのメタマテリアル・アブソーバーは自由空間での利用 を想定しているため, 基板上の広範囲にメタマテリアル がアレイ配置されている ${ }^{5-13)}$.

近年, 次世代光集積回路の実現に向けてシリコン $(\mathrm{Si})$ を材料としたシリコンフォトニクスが注目を集めてい
$ろ^{14)}$. Siは光通信波長の $1550 \mathrm{~nm}$ 付近において 3.4 程度の 高い屈折率を持ち，低損失であるため，従来の石英系光 回路より小型・集積化に適している. シリコンフォトニ クスを実現するための一要素として光減衰器がある。光 減衰器は, 光通信素子の終端器としての利用や, 光波長 合分波器・光ファイバアンプに内蔵され利得の制御に用 いられている。シリコンフォトニクス向けに試作された 光減衰器に，マッハツェンダー干渉計 (Mach Zehnder Interferometer: MZI) 型 ${ }^{15)}$ とキャリア吸収型 ${ }^{16)}$ がある。 MZI 型光減衰器は, 方向性結合器を利用し光を光路長の異な る二つの経路へと分岐させ，再び結合させることで位相 の異なる二つの光の干渉を起こし, 出力光の強度を制御 する，文献15)の試作例では，結合器の長さに450 $\mu \mathrm{m}$ を 要する。また，半導体のキャリアによる光の吸収を利用 した光減衰器は, Si導波路にPINダイオード構造を作り, キャリアを注入することで光の減衰量を制御する。キャ リアによる光吸収は小さいため, 文献16)の試作例では, 減衰器の長さに $1 \mathrm{~mm}$ 程度を要する.

メタマテリアルを光集積回路に適用した事例として, 雨宮らは, InP系光導波路とメタマテリアルを融合した 光変調器を試作・評価した17)。メタマテリアルによる大 きな屈折率変調を利用することで, 素子の小型化・高性 能化が期待できる.

本論文では，金属ナノ共振器と $\mathrm{Si}$ 導波路を集積化した 
光減衰器を提案および試作する，共振周波数付近で大き な光吸收特性を有する金属ナノ共振器を利用すること で, 従来のMZI型やキャリア吸収型光減衰器よりも素子 の小型化が期待できる。前述のように，これまでに報告 されているメタマテリアル・アブソーバーは, 自由空間 中の伝搬光とモード結合するものであるが, 本論文で は，導波路表面に局在するエバネッセント波とモード結 合するメタマテリアル・アブソーバーを実現する.

\section{2. 光減衰器の動作原理}

Fig. 1に, 光減衰器の概念図を示す. $\mathrm{Si}$ 導波路と $\mathrm{Au}$ ノロッドのアレイが近接配置されている，光が導波路を 伝搬するとき，導波路外周にエバネッセント波が浸み出 す. Auナノロッドはナノ共振器として機能し, 共振波 長の光を効率的に吸収する(ジュール熱や放射光として 散逸する)ので，共振波長のエバネッセント波がAuナノ ロッドのSPPモードと結合するとき，伝搬光は減衰す る.

Fig. 2に， $\mathrm{Si}$ 導波路を伝搬する電磁波モードの計算例 を示す。実際の測定に合わせ，シングルモードのTE モードを用いた。 なお， TEモードは，電界を $E$, 磁界を $H$ とすると， $\left(E_{\mathrm{x}}, H_{\mathrm{y}}, H_{\mathrm{z}}\right)$ 成分を持つ。幅 $400 \mathrm{~nm}$ ，厚さ $260 \mathrm{~nm}$ の矩形断面の $\mathrm{Si}$ 導波路が $\mathrm{SiO}_{2}$ 基板上に形成されて いる，計算には，有限要素法に基づく市販の電磁界モー ドソルバ(FemSIM, Synopsys社)を用いた。 入射波長は $1550 \mathrm{~nm}$ と $, \mathrm{Si}, \mathrm{SiO}_{2}$ および空気の屈折率はそれぞれ 3.52，1.44，1.0とした. Fig. 2(a)より， $E_{\mathrm{x}}$ 成分のエバ ネッセント波が導波路外部へ浸み出していることが分か る. Fig. 2(b) は， $H_{\mathrm{y}}$ 成分のモードを示すが，導波路外部 への浸み出しは主に導波路上下方向に対してであり, $\mathrm{Au}$ ナノロッドを配置する水平方向への浸み出しは少な い，従って， $E_{\mathrm{x}}$ 成分によって励振されるSPPモードを持 つAuナノロッドを導波路の横に配置すれば，効率的に 光を吸収できることになる。

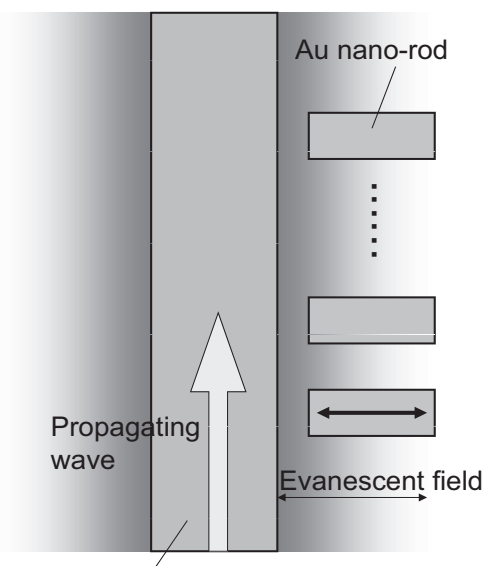

Si waveguide

Fig. 1 A schematic view of a wavelength-selective optical attenuator. (a)

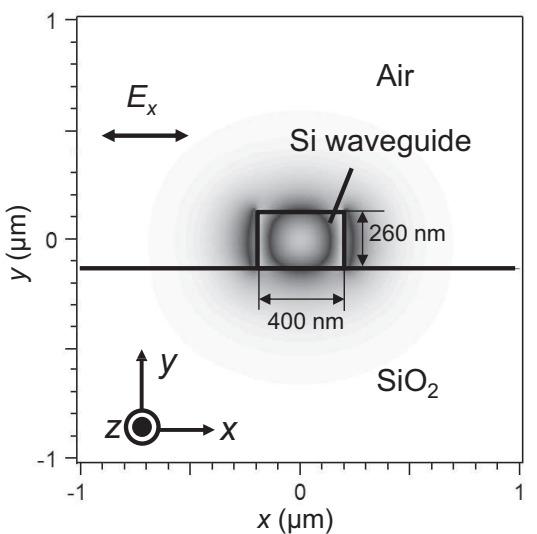

(b)
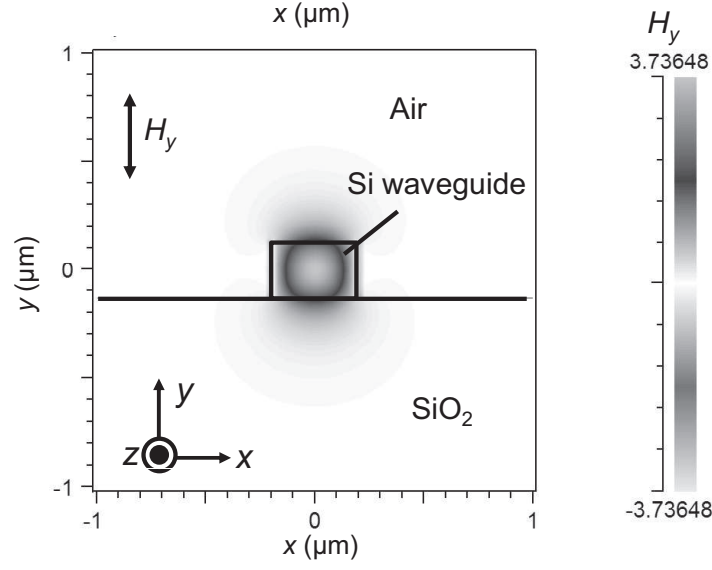

Fig. 2 Cross sections of calculated (a) electric and (b) magnetic fields of an Si waveguide.

\section{3. 設計}

Fig. 3に, 提案する光減衰器の計算モデルを示す. $\mathrm{SiO}_{2}$ 層上に幅 $400 \mathrm{~nm}$ ，厚さ260 nmの $\mathrm{Si}$ 導波路があり，導

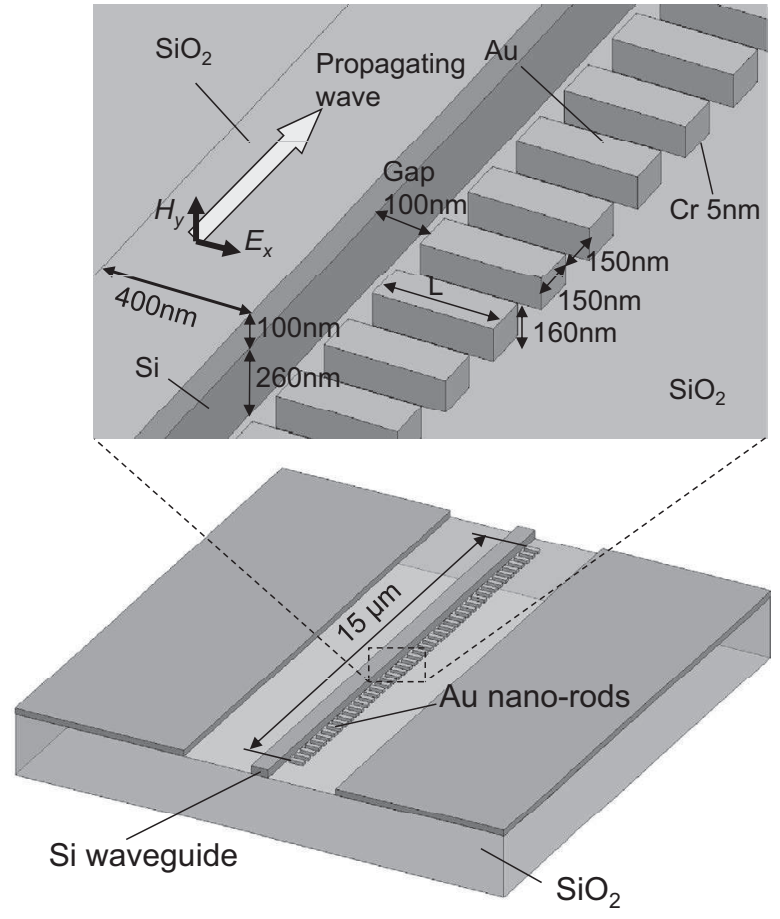

Fig. 3 The calculation model. 
波路の側面から $100 \mathrm{~nm}$ 離れて $\mathrm{Au}$ ナノロッドが配置され ている.Auナノロッドは, 幅 $150 \mathrm{~nm}$, 厚さ $160 \mathrm{~nm}$, 長 さしの長方形の形状をユニットとして, それが導波路に 沿って周期 $300 \mathrm{~nm}$ で50個配列されている。導波路高さ とAuナノロッド高さの中心は一致している。計算は, 有限差分時間領域法に基づく市販の電磁界解析ソフト (FullWAVE，Synopsys社）を用いた，入射光としてパル ス波を用い, 減衰器通過後の伝搬波を離散フーリエ変換 することで透過スペクトルを求めた。

Fig. 4に, Auナノロッドの長さLをパラメータとした 透過スペクトルの計算值を示す。Auナノロッドの影響 により伝搬光が減衰し，Lを350，400，450 nmと長くす ることで，減衰ピークの位置が長波長側へシフトするこ とが分かる。また，長波長側ほど減衰量が大きくなって いる。これは，長波長ほどエバネッセント波の浸み出し が長くなることに加え, 共振器長も長くなるので, エバ ネッセント波と相互作用する体積が実質的に増えるため だと考えられる。A ピーク波長を制御できることが分かる．例えば， $L=400$ $\mathrm{nm}$ の場合, $1525 \mathrm{~nm}$ 中心として-26dBの減衰が得られ る.

次に, $\mathrm{Au}$ ナノロッド $(L=400 \mathrm{~nm})$ と $\mathrm{Au}$ 平板との減衰特 性の比較を行った。Figs. 5(a)，5(b)に，それぞれの寸 法を示す。 $\mathrm{Au}$ 平板は, 幅 $1 \mu \mathrm{m}$, 長さ $15 \mu \mathrm{m}$ で, 厚さ $(160$ $\mathrm{nm})$ および導波路との間隔 $(100 \mathrm{~nm})$ はAuナノロッドと 同じである. Fig. 5 (c)に透過スペクトルを示す. Au平板 が導波路に近接していても減衰はほぼ無いことが分か る.

Fig. 6に, Auナノロッドによる減衰のピーク波長であ る, 波長 $1525 \mathrm{~nm}$ の連続波を $\mathrm{Si}$ 導波路に入力したときの 電界 $\left(E_{\mathrm{x}}\right)$ の分布を示す。エバネッセント波を介して $\mathrm{Si}$ 導 波路と $\mathrm{Au}$ ナノロッドがモード結合し, Auナノロッドの 光吸収特性により電界 $\left(E_{\mathrm{x}}\right)$ が減衰している様子が分か る.

$\mathrm{Au}$ ナノロッドの共振モードを調べるため, Fig. 6と同 じ条件で計算した磁界 $\left(H_{\mathrm{y}}\right)$ の分布を示す (Fig. 7). 電界 $\left(E_{\mathrm{x}}\right)$ のエバネッセント波によりAuナノロッドの自由電 子が励起され長手方向に振動し, 図中の矢印で示す方向 に電流が流れる。このとき, 電流の向きは交互に入れ替

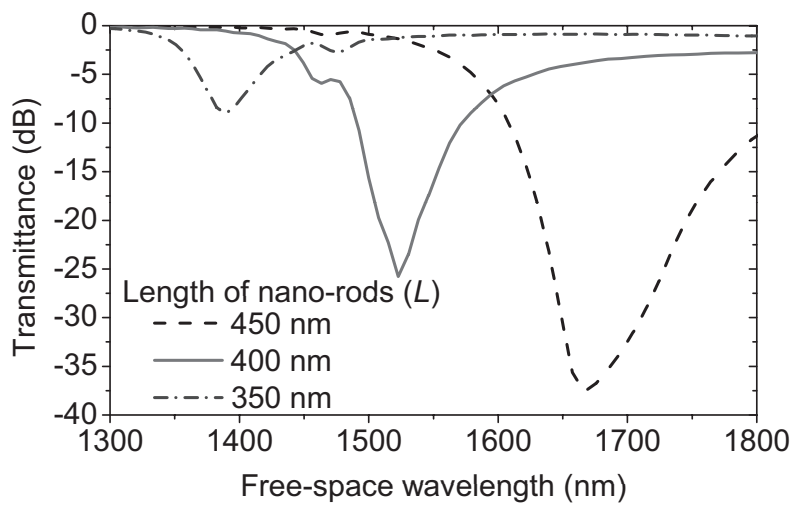

Fig. 4 Calculated transmittance spectra for nano-rod lengths of 350,400 , and $450 \mathrm{~nm}$.

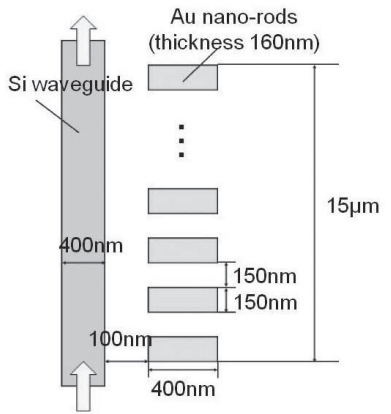

(a)

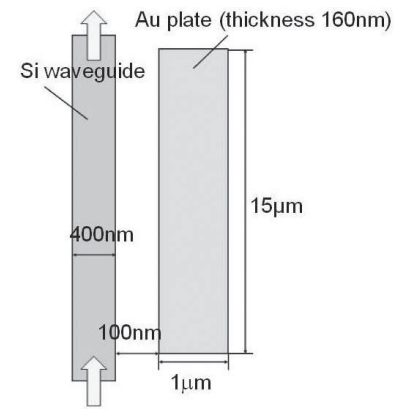

(b)

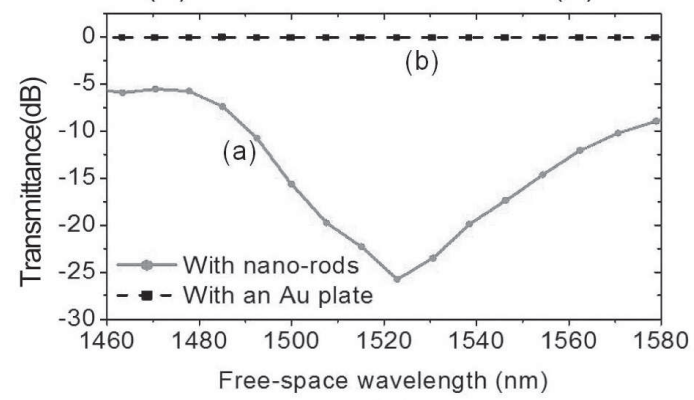

(c)

Fig. 5 Comparison of calculated transmittance spectra between $\mathrm{Au}$ nano-rods and an $\mathrm{Au}$ plate. Calculation models of Si waveguides with (a) Au nano-rods and (b) an Au plate.

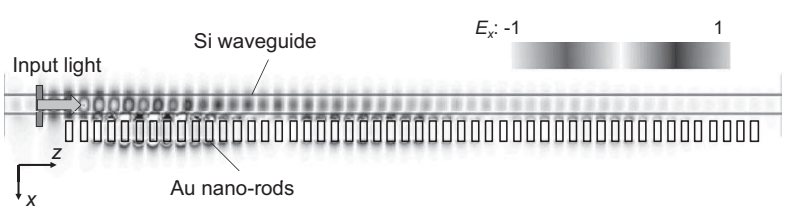

Fig. 6 A top view of calculated electric field $\left(E_{\mathrm{x}}\right)$ of an $\mathrm{Si}$ waveguide with Au nano-rods.

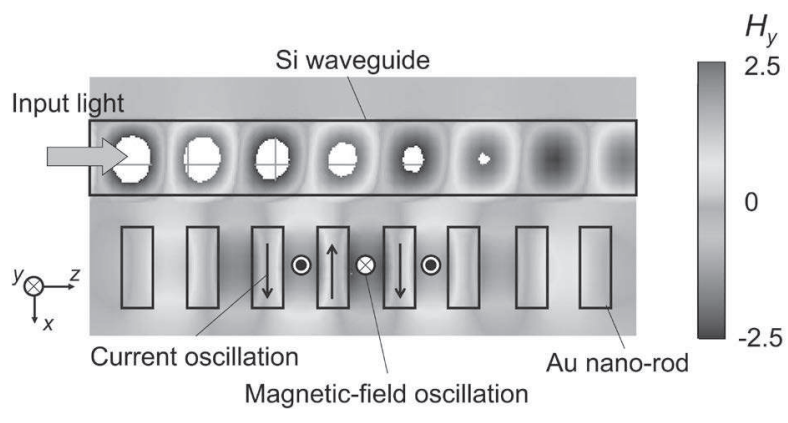

Fig. 7 A top view of calculated magnetic field $\left(H_{\mathrm{y}}\right)$ of an Si waveguide with Au nano-rods.

わっているため, Auナノロッド間の空間にェy方向の磁 界が励振され，隣接するAuナノロッド間で共振器の構 造を形成している.

\section{4. 製 作}

Fig. 8に，製作工程の概要を示す。製作には， Silicon-on-insulator (SOI) 基板を用いた (Fig. 8 (a)). はじめ に, 電子線 (Electron beam: EB) 描画用の $\mathrm{Au} / \mathrm{Cr}$ のアライ メントマークを製作する (Fig. 8(b))。製作工程中にEB描 
(a) An SOI wafer

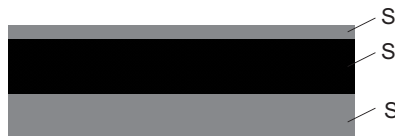

(b) Au/Cr deposition and patterning for alignment marks

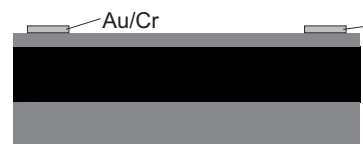

(c) Fast atom beam etching for a Si waveguide

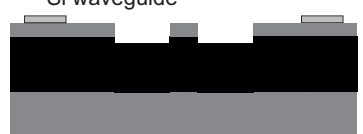

(d) $\mathrm{SiO}_{2}$ deposition and patterning for making Au nano-rod bases

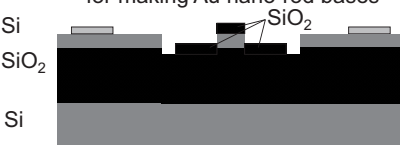

(e) $\mathrm{Au} / \mathrm{Cr}$ deposition and patterning for Au nano-rods $\mathrm{Au} / \mathrm{Cr}$

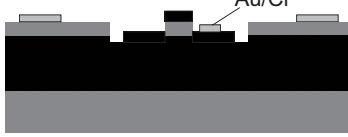

(f) Cleaving of an SOI wafer
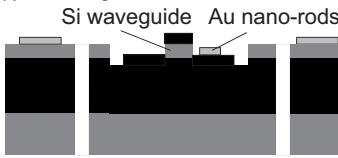

Fig. 8 Process steps.

画を3回行い，各描画パターンを高精度にアライメント する必要があるため, アライメントマークの製作が必要 になる。アライメントマークは, EB描画によりレジス トパターン形成後, $\mathrm{EB}$ 蒸着による $\mathrm{Au} / \mathrm{Cr}$ 成膜およびリフ トオフ法により製作する。次に， $\mathrm{Si}$ 導波路を製作する。 $\mathrm{EB}$ 描画により $\mathrm{Si}$ 導波路パターンを描画後, 高速原子線 ( $\mathrm{SF}_{6}$ ガス) エッチングにより上部Si層を加工する (Fig. 8 (c)). 次に, $\mathrm{Si}$ 導波路と $\mathrm{Au}$ ナノロッドの高さを合わせる ため, $\mathrm{EB}$ 描画, $\mathrm{SiO}_{2}$ のEB蒸着, リフトオフ法により, $\mathrm{Au}$ ナノロッドの土台を形成する $(\mathrm{Fig} .8(\mathrm{~d}))$. 次に, EB 描画, $\mathrm{Au} / \mathrm{Cr}$ のB蒸着, リフトオフ法により, $\mathrm{Au}$ ナノ ロッドを製作する $($ Fig. $8(\mathrm{e}))$ ）最後に，基板亭側よりダ イシングソーで溝入れを行い, 溝に沿って基板を䢃開す ることで1チップが完成する(Fig. 8(f))。なお, CrはAuと 下地との密着層として用いており, 厚さ $5 \mathrm{~nm}$ 程度である。

Fig. 9に，製作した減衰器のSEM写真を示す． Si導波 路近傍に，Auナノロッドが高精度に製作されているこ とが分かる. Fig. 9(b)に示した厚さは, 別領域に形成し た段差評価用パターンを触針式段差計で測定した。 $\mathrm{Au}$ の厚さは設計值160 nmに対して実測值 $150 \mathrm{~nm}$ となっ た.また, Fig. 9(c)に示した寸法は, SEM像から測定し た(設計值との誤差をTable 1にまとめた).
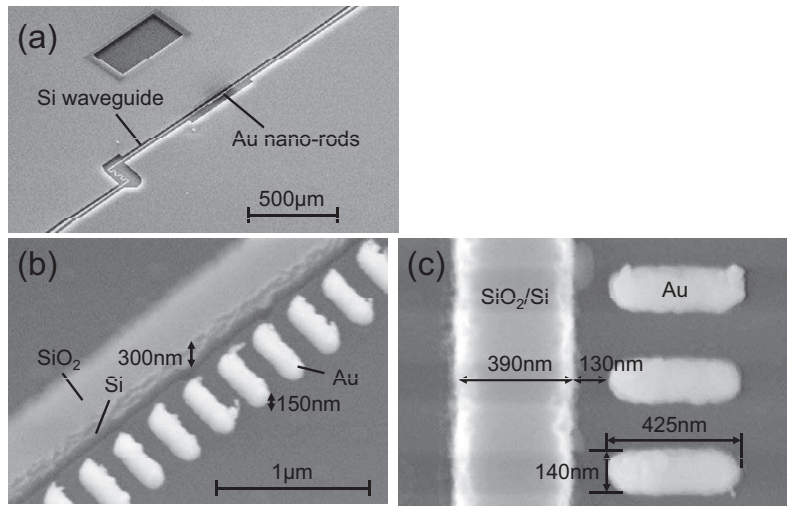

Fig. 9 SEM pictures of fabricated device. (a) Overall perspective view, (b) magnified perspective view of $\mathrm{Au}$ nano-rods, and (c) magnified top view of $\mathrm{Au}$ nano-rods.

Table 1 Comparison between designed and fabricated dimensions.

\begin{tabular}{|c|c|c|c|}
\hline & Design & Measurement & Error \\
\hline \hline Width of waveguide & $400 \mathrm{~nm}$ & $390 \mathrm{~nm}$ & $-10 \mathrm{~nm}$ \\
\hline Length of nano-rod & $400 \mathrm{~nm}$ & $425 \mathrm{~nm}$ & $+25 \mathrm{~nm}$ \\
\hline Width of nano-rod & $150 \mathrm{~nm}$ & $140 \mathrm{~nm}$ & $-10 \mathrm{~nm}$ \\
\hline Gap & $100 \mathrm{~nm}$ & $130 \mathrm{~nm}$ & $+30 \mathrm{~nm}$ \\
\hline
\end{tabular}

\section{5. 光学測定}

Fig. 10に，透過スペクトルの測定結果を示す．Au構 造無し, $\mathrm{Au}$ 平板, $\mathrm{Au}$ ナノロッドの3種類を製作し，透過 スペクトルを比較した。測定した構造のSEM写真を各 透過スペクトルの挿入図に示す. Figs. $10(\mathrm{a}), 10(\mathrm{~b})$ を比 較すると, $\mathrm{Au}$ 構造無しと $\mathrm{Au}$ 平板ともに大きな減衰ピー クは見られず，両者に大きな差は無いことが分かる。一 方, Fig. 10 (c)のAuナノロッドがある場合の透過スペク トルは, 幾つかの減衰ピークが確認され, 波長 $1565 \mathrm{~nm}$ において $-17.7 \mathrm{~dB}$ の大きな減衰(波長 $1513 \mathrm{~nm}$ の透過率と 比較)を確認することができた。

Fig. 11に，計算值と測定值の比較を示す。計算モデル は，製作した減衰器の測定寸法を基に構築した(Fig. 11

(a)

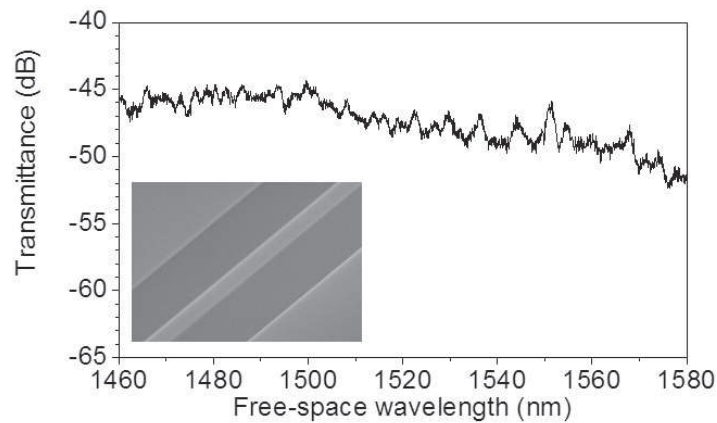

(b)

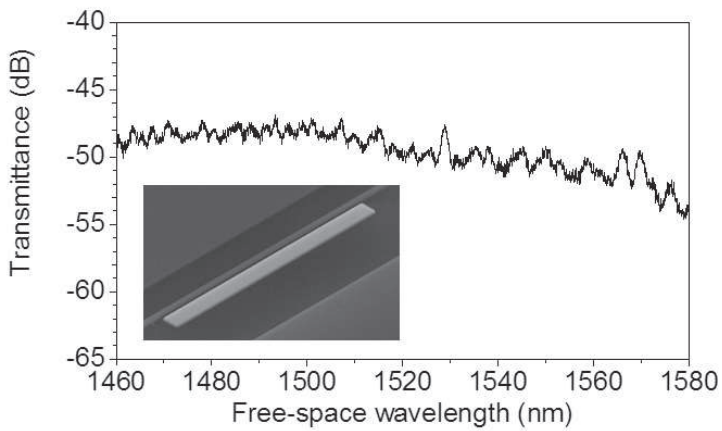

(c)

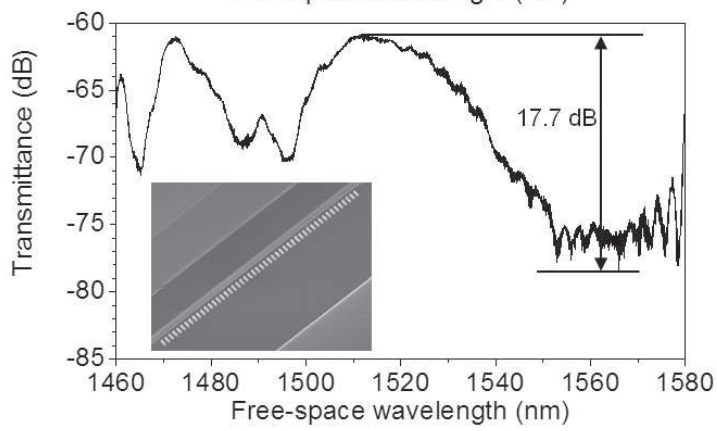

Fig. 10 Measured transmittance spectra of Si waveguides (a) without $\mathrm{Au}$ structures, (b) with an Au plate, and (c) with an Au nano-rods. The SEM pictures of respective devices are shown in insets. 
上部に示す)。計算によると，Auナノロッドの共振によ る減衰により，波長1587 nmで-25.8dBの大きな減衰 (波 長1470 nmの透過率と比較)を示すことが分かる。一方, 測定值は，波長1465，1487，1495，1565 nmで減衰がみ られる。波長 $1565 \mathrm{~nm}$ の減衰が, Auナノロッドの共振に よる減衰と考えられ, 計算值と比較すると短波長側にシ フトして減衰量も小さいが, これは形状の丸みや表面の 荒れに起因する計算モデルと実際の形状の差異によるも のと考えられる。測定值のみに見られる波長 1465 , 1487, $1495 \mathrm{~nm}$ での小さな減衰が生じる原因を断定する に至っていないが，これも製作のばらつきや表面荒れに 起因するものと考えられる.

次に，透過率の減衰が吸収と反射のどちらに起因する のか, 計算により見積もった. Fig. 11の計算モデルか ら，Auナノロッドによる反射スペクトルを計算した (Fig. 12)。計算上, 大きな減衰が生じる波長 $1587 \mathrm{~nm}$ 付 近における反射は $0.1 \%(-20 \mathrm{~dB})$ 程度となっており, $\mathrm{Au}$ ナノロッドによる反射は少ない。従って，Auナノロッ ドの共振波長において, 導波路を伝搬する光は効率的に 吸収されると見積もられる。

\section{6. まとめ}

$\mathrm{Au}$ ナノロッドと $\mathrm{Si}$ 導波路を集積化した波長選択減衰 器を提案および試作した。Auナノロッドは光共振器と して機能し, 共振波長の光を効率的に吸収する. 有限差 分時間領域法に基づく計算により，通信波長帯で減衰 ピークを持つ減衰器の設計を行った。幅 $140 \mathrm{~nm}$, 長さ

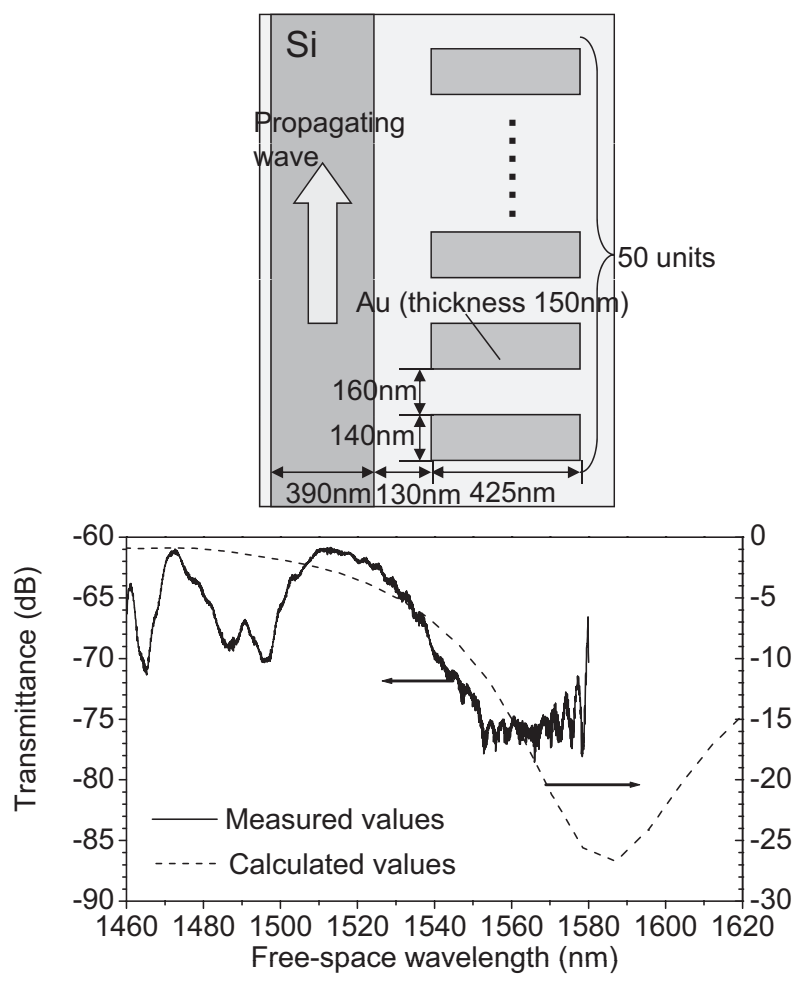

Fig. 11 Comparison between measured and calculated transmittance spectra. A calculation model is illustrated on the upper part.

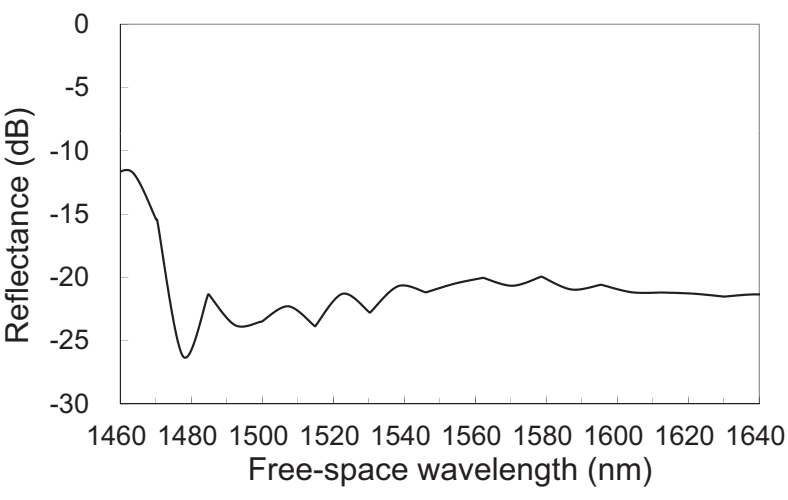

Fig. 12 Calculated reflectance spectra. The calculation model is shown on the upper part in Fig. 11.

$425 \mathrm{~nm}$ の Auナノロッドを周期 $300 \mathrm{~nm}$ で50個配置した全 長15 $\mu \mathrm{m}$ の小型減衰器を $\mathrm{Si}$ 導波路から $130 \mathrm{~nm}$ 離れた側部 に製作できた。透過スペクトル測定の結果，波長 1565 $\mathrm{nm}$ において $17.7 \mathrm{~dB}$ の大きな減衰を確認することがで きた。

\section{謝 辞}

本研究の一部は，科研費25109702，23109503の支援を 受け，製作は東北大学マイクロ・ナノマシニング研究教 育センターの設備を用いて行われた。

\section{参考文献}

1) R. A. Shelby, D. R. Smith, and S. Schultz: Science 292 (2001) 77.

2) V. M. Shalaev: Nat. Photon. 1 (2007) 41.

3) D. Schurig, J. J. Mock, B. J. Justice, S. A. Cummer, J. B. Pendry, A. F. Starr, and D. R. Smith: Science 314 (2006) 977.

4) J. Zhou, Th. Koschny, M. Kafesaki, E. N. Economou, J. B. Pendry, and C. M. Soukoulis: Phys. Rev. Lett. 95 (2005) 223902.

5) B. Zhang, Y. Zhao, Q. Hao, B. Kiraly, I.-C. Khoo, S. Chen, and T. J. Huang: Opt. Express 19 (2011) 15221

6) L. Meng, D. Zhao, Q. Li, and M. Qiu: Opt. Express 21 (2012) A111.

7) C. Hu, Z. Zhao, X. Chen, and X. Luo: Opt. Express 17 (2009) 11039.

8) X. Liu, T. Starr, A. F. Starr, and W. J. Padilla: Phys. Rev. Lett. 104 (2010) 207403.

9) X. Liu, T. Tyler, T. Starr, A. F. Starr, N. M. Jokerst, and W. J. Padilla: Phys. Rev. Lett. 107 (2011) 045901.

10) H.-T. Chen: Opt. Express 20 (2012) 7165.

11) L. Huang, D. R. Chowdhury, S. Ramani, M. T. Reiten, S.-N. Luo, A. J. Taylor, and H.-T. Chen: Opt. Lett. 37 (2012) 154.

12) M. P. Hokmabadi, D. S. Wilbert, P. Kung, and S. M. Kim: Terahertz Sci. Technol. 6 (2013) 40.

13) H. Tao, N. I. Landy, C. M.Bingham, X. Zhang, R. D. Averitt, and W. J. Padila: Opt. Express 16 (2008) 7181

14) T. Tsuchizawa, K. Yamada, H. Fukuda, T. Watanabe, J. Takahashi, M. Takahashi, T. Shoji, E. Tamechika, S. Itabashi, and H. Morita: IEEE J. Select. Topics Quant. Electron. 11 (2005) 232.

15) T. Tsuchizawa, K. Yamada, H. Fukuda, T. Watanabe, S. Uchiyama, and S. Itabashi: Jpn. J. Appl. Phys. 45 (2006) 6658.

16）山田 浩治，土澤 泰，渡辺 俊文，福田浩，篠島弘幸，板橋 聖一：レーザー研究 35 (2007) 550.

17) T. Amemiya, A. Ishikawa, T. Kanazawa, J. Kang, N. Nishiyama, Y. Miyamoto, T. Tanaka, and S. Arai: Sci. Rep. 5 (2015) 8985. 